\title{
INTERNATIONAL DIFFUSION OF FOOD SAFETY STANDARDS: THE ROLE OF DOMESTIC CERTIFIERS AND INTERNATIONAL TRADE
}

\author{
REZGAR MOHAMMED \\ Department of Agricultural and Applied Economics, Texas Tech University, Lubbock, Texas \\ YUQING ZHENG* \\ Department of Agricultural Economics, University of Kentucky, Lexington, Kentucky
}

\begin{abstract}
We examined the cross-national adoption of six major private food safety standards, focusing on the role of certifiers and international trade. Results show that the number of certification bodies existing in the domestic country, food exports, and the proportion of food exports to North America had positive effects on a country's adoption of food safety standards. Distance leads to product differentiation for the standards and therefore disadvantages developing countries in Africa and Asia for adopting the standards, which are all based in the United States or Europe. Providing these countries with better access to certifiers can alleviate this geographic disadvantage.
\end{abstract}

Keywords. Adoption, certification bodies, food exports, food safety standard, private food standard, third-party certification

JEL Classifications:. Q13, Q17, Q18

\section{Introduction}

\subsection{Motivation}

Food safety breaches can cause significant economic losses to producers, sickness to consumers, diminished consumer confidence in the safety of the food supply, and widespread social distress. In 2014 alone, the United States had 94 recalls of meat and poultry and 491 recalls of other food products, up from 53 and 225 in 2005, respectively, exposing our weakness in the food safety net. ${ }^{1}$ Private food safety certification has emerged as a prominent and influential regulatory

The authors thank the editor and two anonymous reviewers of this journal for their helpful comments and suggestions. Any remaining errors are the authors'.

*Corresponding author's e-mail: yuqing.zheng@uky.edu

1 Source: U.S. Department of Agriculture, Food Safety and Inspection Service (2015) and the U.S. Food and Drug Administration (2015). 
mechanism in both the private (e.g., requirement imposed on suppliers by major retailers) and public spheres (e.g., the new Food Safety Modernization Act's [FSMA] requirement on importers) of the contemporary agrifood system.

The certification process starts with a producer (farmer or food manufacturer) choosing a food safety standard out of its own interest or as a requirement of government or buyers (e.g., retailers or importers). The major private food safety standards recognized by the Global Food Safety Initiative, an important international benchmarking institution, are British Retail Consortium Food Standard (BRC), Food Safety System Certification 22000 (FSSC 22000), Global Good Agricultural Practices (GlobalGAP), International Featured Standards Foods (IFS), International Organization for Standardization 22000 (ISO 22000), PrimusGFS (developed by PrimusLab as a Global Food Safety Initiative variant), and Safe Quality Food (SQF). After deciding on the standard, the producer chooses an accredited third-party certifier (also known as a certification body) under that standard that will conduct an audit.

Certification bodies are private firms (for profit or nonprofit) that hire certifiers/auditors to offer independent verification that the producers meet the requirements of a certain standard. To be able to offer food safety certification, a certification body will need to apply to the standard holder, get accredited, and train qualified auditors. In general, qualified auditors should have an appropriate higher education, audit and work experience (about 5 years), and complete training in the specified standard that usually has a time requirement such as a few days. ${ }^{2}$ For example, BRC offers a 2-day course frequently for auditor training in many locations in the United Kingdom, United States, Canada, and Chile. The cost is around US $\$ 1,000$. Some certification bodies focus on food safety certification, whereas most others offer a wider variety of certifications such as general quality management system (ISO 9001). In 2011, the U.S. Food and Drug Administration (FDA) estimated there were about 568 certification bodies worldwide offering food safety audits. It is also worth noting that a certification body can offer certification to several food safety standards and can choose to offer different standards in different countries. ${ }^{3}$ Finally, after going through an auditing process, the producer needs to fix nonconformities identified by the certification body in order to get certified. Certification needs to be renewed on a regular basis (normally 1 year).

The aim of this article is to examine cross-national adoption of private food safety standards, focusing on the role of certifiers and international trade. The cost of obtaining certification largely consists of auditing fees (usually billed by

2 Source: BRC website, "How to Become a BRC Global Standards Auditor," http://www. brcglobalstandards.com/partners/certification-bodies/how-to-become-a-brc-global-standards-auditor/ (accessed March 1, 2017).

3 For example, Bureau Veritas, a leading international certification body headquartered in France, offers certification to six and three of the aforementioned food safety standards in North America and China, respectively. 
hour), preparation and compliance cost, and auditors' travel expenses. Although normally the smallest cost of the three, travel cost can be cumbersome especially to developing countries. For example, suppliers in developing countries who are seeking certification sometimes have to pay for travel and living expenses of certifiers from industrialized nations (Barrett et al., 2002). In Ghana, most growers seeking third-party food safety certification are required to bring in certifiers from Europe (Hatanaka, Bain, and Busch, 2005). As mentioned by Barrett et al. (2002), the likelihood of adopting certificates might increase with the existence of a local auditor. ${ }^{4}$ In fact, Herzfeld, Drescher, and Grebitus (2011) showed that the existence of a domestic certification body had a significant impact on the cross-national adoption of both GlobalGAP and BRC certificates. In this article, we aim to further quantify how the number of certification bodies existing in the domestic country and the distance to the standard holder's country affect a country's adoption of the major food safety standards.

Our analysis of the relationship between trade and certification adoption fits in the broad literature of food attributes. The main strand of this literature evaluates how consumers value various food attributes such as organics (e.g., McCluskey and Loureiro, 2003; Meas et al., 2015), genetically modified organisms (e.g., Liaukonyte et al., 2013), country of origin (e.g., Lim et al., 2014; Loureiro and Umberger, 2007), and recombinant bovine somatotropin (rbST)-free milk (e.g., Kanter, Messer, and Kaiser, 2009; Runge and Jackson, 2000). Another strand of this literature focuses on how food attributes (or requirements on attributes) could affect producers and trade. For example, many studies empirically examined how food safety requirements (e.g., sanitary and phytosanitary measures and maximum residual limit) can affect food imports (e.g., Jongwanich, 2009; Otsuki, Wilson, and Sewadeh, 2001a, 2001b; Peterson et al., 2013). Several studies examined the impact of food safety standards on producers' levels of production or revenues by focusing on the GlobalGAP standard and using data from developing countries. For example, Henson, Masakure, and Cranfield (2011) found that GlobalGAP certification had a positive effect on firm export sales performance for the fresh produce industry in countries in sub-Saharan Africa. Other examples include Asfaw, Mithöfer, and Waibel (2009, 2010) and Kariuki, Loy, and Herzfeld (2012) for Kenya, Subervie and Vagneron (2013) for Madagascar, and Holzapfel and Wollni (2014) for Thailand.

It is worth noting that the number and size of food safety certified sites have been ignored in the aforementioned literature. One purpose of our study is to highlight this aspect of this often neglected issue, by focusing on the relationship between the number of food safety certified sites and food trade. On one hand, the

4 For example, China has about 40 certification bodies that offer food safety certifications, with most being domestic and a handful of international ones such as Intertek and DNV. In the last decade, China has experienced a large increase in the number of sites certified to food safety standards. 
number of food safety certified sites might enhance food exports by improving the level of food safety. Two studies that examined how certification affects food exports include Henson, Masakure, and Cranfield (2011) and Zheng, Muth, and Brophy (2013). In particular, Zheng, Muth, and Brophy (2013) found that China's aggregate food exports to the United States were positively associated with the number of BRC, GlobalGAP, or ISO 22000 certified sites in China. On the other hand, trade and trade relationship might spur further adoption of certification. A food export-oriented economy could have a higher demand for food safety certification in order to maintain/strengthen the competitive advantage in international market. A country with a close trade relationship with Europe generally will have a higher demand for the standards that are popular in Europe as well. We will address the important, but yet unanswered, question of whether the international relationship of food trade affects the adoption of a country's food safety certification. In particular, because the food safety certification requirement has been imposed by many developed countries on suppliers in developing countries, we hypothesize that a country's food exports to the European Union and/or North America would positively affect the adoption of food safety certification. Suppliers in developing countries may also have voluntarily used certification to gain market access to developed countries. In addition, we also explore whether a higher export share of more perishable food will result in a higher demand for certification.

Our study builds on Herzfeld, Drescher, and Grebitus's (2011) study of cross-national adoption of GlobalGAP and BRC standards but extends the analysis in three significant ways. First, our sample size is much larger by covering all the aforementioned food safety standards except IFS (IFS does not publicly disclose information on certified sites). Second, we use the number of certification bodies present in the domestic country rather than the presence of a domestic certification body for a standard, allowing us to quantify the impact of adding an additional certification body. Third, by including a country's food exports to each continent and a breakdown of food exports by type, we specifically model the impact of trade relations on the diffusion of food safety standards. We found that an increase of one domestic certification body increased the number of certified sites by 3.9, highlighting the importance of providing easy access to trained auditors in developing countries. Furthermore, a country's adoption of certification is negatively related to the distance to the standard holder's country (where the standard originated from), and positively

affected by total food exports and by the proportion of food exported to North America.

\subsection{Adoption and Distribution of Standards by Country}

In Table 1, we included the number of certified sites to each standard (except IFS, for which we do not have data) broken down by country for the year of 2013. Note that because a producer can have multiple sites certified to the same 
Table 1. Certified Sites by Country and Standard, 2013

\begin{tabular}{|c|c|c|c|c|c|c|c|}
\hline Country & BRC & $\begin{array}{l}\text { FSSC } \\
22000\end{array}$ & GlobalGAP & $\begin{array}{l}\text { ISO } \\
22000\end{array}$ & PrimusGFS & SQF & $\begin{array}{l}\text { HHI across } \\
\text { Standards }\end{array}$ \\
\hline Afghanistan & 0 & 0 & 0 & 1 & 0 & 0 & 1 \\
\hline Albania & 1 & 0 & 0 & 7 & 0 & 0 & 0.78 \\
\hline Algeria & 0 & 3 & 0 & 11 & 0 & 0 & 0.66 \\
\hline Argentina & 108 & 112 & 880 & 117 & 2 & 0 & 0.55 \\
\hline Armenia & 2 & 1 & 1 & 11 & 0 & 0 & 0.56 \\
\hline Australia & 286 & 94 & 117 & 143 & 0 & 869 & 0.39 \\
\hline Austria & 59 & 85 & 2,619 & 72 & 0 & 0 & 0.86 \\
\hline Azerbaijan & 2 & 3 & 1 & 9 & 0 & 0 & 0.42 \\
\hline Bahamas & 1 & 0 & 0 & 0 & 0 & 0 & 1 \\
\hline Barbados & 0 & 2 & 0 & 0 & 0 & 0 & 1 \\
\hline Belarus & 7 & 15 & 0 & 14 & 0 & 0 & 0.36 \\
\hline Belgium & 585 & 116 & 3,185 & 200 & 0 & 0 & 0.63 \\
\hline Belize & 1 & 0 & 0 & 0 & 9 & 0 & 0.82 \\
\hline Benin & 0 & 0 & 0 & 0 & 0 & 0 & NA \\
\hline Bolivia & 1 & 10 & 2 & 25 & 0 & 0 & 0.51 \\
\hline $\begin{array}{l}\text { Bosnia and } \\
\text { Herzegovina }\end{array}$ & 2 & 6 & 204 & 17 & 0 & 0 & 0.8 \\
\hline Botswana & 2 & 1 & 0 & 1 & 0 & 0 & 0.38 \\
\hline Brazil & 116 & 237 & 1,146 & 198 & 0 & 4 & 0.49 \\
\hline Brunei & 0 & 1 & 0 & 3 & 0 & 0 & 0.63 \\
\hline Bulgaria & 29 & 80 & 26 & 244 & 0 & 0 & 0.47 \\
\hline Burkina Faso & 0 & 0 & 170 & 0 & 0 & 0 & 1 \\
\hline Burundi & 0 & 0 & 0 & 0 & 0 & 0 & NA \\
\hline Cambodia & 0 & 1 & 0 & 1 & 0 & 0 & 0.5 \\
\hline Canada & 473 & 222 & 33 & 54 & 162 & 546 & 0.27 \\
\hline $\begin{array}{l}\text { Central African } \\
\text { Republic }\end{array}$ & 0 & 0 & 0 & 0 & 0 & 0 & NA \\
\hline Chile & 225 & 29 & 3,195 & 85 & 8 & 2 & 0.82 \\
\hline China & 1,738 & 775 & 291 & 9,406 & 0 & 6 & 0.62 \\
\hline Colombia & 11 & 24 & 724 & 58 & 0 & 2 & 0.79 \\
\hline Congo, Republic of & 0 & 1 & 0 & 7 & 0 & 0 & 0.78 \\
\hline Costa Rica & 17 & 40 & 314 & 9 & 0 & 6 & 0.68 \\
\hline Côte D'Ivoire & 8 & 5 & 686 & 0 & 0 & 0 & 0.96 \\
\hline Croatia & 14 & 36 & 130 & 97 & 0 & 0 & 0.36 \\
\hline Cyprus & 26 & 4 & 1,111 & 143 & 0 & 0 & 0.76 \\
\hline Czech Republic & 137 & 96 & 97 & 159 & 0 & 0 & 0.26 \\
\hline Denmark & 148 & 60 & 269 & 155 & 0 & 0 & 0.31 \\
\hline $\begin{array}{l}\text { Dominican } \\
\text { Republic }\end{array}$ & 1 & 6 & 993 & 3 & 2 & 1 & 0.97 \\
\hline Ecuador & 30 & 17 & 926 & 26 & 0 & 5 & 0.85 \\
\hline Egypt & 160 & 33 & 772 & 296 & 0 & 0 & 0.45 \\
\hline El Salvador & 2 & 5 & 0 & 10 & 0 & 1 & 0.4 \\
\hline Estonia & 11 & 2 & 1 & 22 & 0 & 0 & 0.47 \\
\hline Ethiopia & 7 & 0 & 18 & 23 & 0 & 0 & 0.39 \\
\hline Fiji & 0 & 3 & 1 & 4 & 0 & 6 & 0.32 \\
\hline Finland & 33 & 49 & 0 & 117 & 0 & 0 & 0.43 \\
\hline Gambia & 1 & 0 & 2 & 0 & 0 & 0 & 0.56 \\
\hline Georgia & 1 & 3 & 2 & 16 & 0 & 0 & 0.56 \\
\hline
\end{tabular}


Table 1. Continued

\begin{tabular}{|c|c|c|c|c|c|c|c|}
\hline Country & $\mathrm{BRC}$ & $\begin{array}{l}\text { FSSC } \\
22000\end{array}$ & GlobalGAP & $\begin{array}{l}\text { ISO } \\
22000\end{array}$ & PrimusGFS & SQF & $\begin{array}{l}\text { HHI across } \\
\text { Standards }\end{array}$ \\
\hline Germany & 603 & 299 & 9,008 & 352 & 0 & 0 & 0.78 \\
\hline Ghana & 13 & 2 & 134 & 5 & 0 & 0 & 0.77 \\
\hline Greece & 264 & 90 & 11,367 & 1,720 & 0 & 0 & 0.73 \\
\hline Guatemala & 13 & 20 & 1,652 & 19 & 3 & 5 & 0.93 \\
\hline Hong Kong, China & 2 & 4 & 0 & 82 & 0 & 0 & 0.87 \\
\hline Hungary & 121 & 46 & 1,279 & 137 & 0 & 0 & 0.67 \\
\hline Iceland & 14 & 2 & 1 & 2 & 0 & 0 & 0.57 \\
\hline India & 481 & 491 & 6,225 & 1,489 & 0 & 15 & 0.55 \\
\hline Indonesia & 94 & 109 & 5 & 262 & 0 & 4 & 0.4 \\
\hline Iraq & 0 & 1 & 0 & 0 & 0 & 0 & 1 \\
\hline Ireland & 381 & 22 & 55 & 42 & 0 & 0 & 0.6 \\
\hline Israel & 174 & 35 & 1,258 & 108 & 0 & 0 & 0.66 \\
\hline Italy & 2,328 & 156 & 20,218 & 781 & 0 & 0 & 0.75 \\
\hline Jamaica & 0 & 6 & 4 & 1 & 0 & 0 & 0.44 \\
\hline Japan & 7 & 701 & 227 & 825 & 0 & 294 & 0.31 \\
\hline Jordan & 9 & 3 & 19 & 38 & 0 & 0 & 0.4 \\
\hline Kazakhstan & 0 & 6 & 0 & 9 & 0 & 0 & 0.52 \\
\hline Kenya & 40 & 28 & 2,326 & 101 & 0 & 0 & 0.87 \\
\hline Kiribati & 0 & 1 & 0 & 0 & 0 & 1 & 0.5 \\
\hline Kuwait & 4 & 3 & 0 & 22 & 0 & 0 & 0.61 \\
\hline Kyrgyzstan & 0 & 1 & 0 & 0 & 0 & 0 & 1 \\
\hline Latvia & 15 & 0 & 4 & 36 & 0 & 0 & 0.51 \\
\hline Lebanon & 3 & 0 & 34 & 73 & 0 & 0 & 0.54 \\
\hline Lithuania & 49 & 12 & 5 & 42 & 0 & 0 & 0.37 \\
\hline Luxembourg & 9 & 2 & 0 & 9 & 0 & 0 & 0.42 \\
\hline Macedonia & 2 & 14 & 23 & 0 & 0 & 0 & 0.48 \\
\hline Madagascar & 2 & 3 & 435 & 1 & 0 & 0 & 0.97 \\
\hline Malawi & 0 & 6 & 0 & 6 & 0 & 0 & 0.5 \\
\hline Malaysia & 42 & 81 & 15 & 389 & 0 & 1 & 0.57 \\
\hline Maldives & 7 & 1 & 0 & 27 & 0 & 0 & 0.64 \\
\hline Malta & 5 & 2 & 47 & 4 & 0 & 0 & 0.67 \\
\hline Mauritania & 0 & 1 & 0 & 0 & 0 & 0 & 1 \\
\hline Mauritius & 13 & 3 & 3 & 17 & 0 & 0 & 0.37 \\
\hline Mexico & 91 & 353 & 669 & 133 & 3,402 & 178 & 0.52 \\
\hline Moldova & 0 & 4 & 2 & 57 & 0 & 0 & 0.82 \\
\hline Mongolia & 0 & 2 & 0 & 2 & 0 & 0 & 0.5 \\
\hline Morocco & 116 & 16 & 717 & 52 & 0 & 0 & 0.65 \\
\hline Mozambique & 1 & 4 & 2 & 5 & 0 & 0 & 0.32 \\
\hline Namibia & 5 & 0 & 35 & 3 & 0 & 0 & 0.68 \\
\hline Nepal & 0 & 3 & 0 & 6 & 0 & 0 & 0.56 \\
\hline Netherlands & 1,312 & 367 & 8,625 & 375 & 0 & 0 & 0.67 \\
\hline New Zealand & 226 & 45 & 1,417 & 21 & 0 & 19 & 0.69 \\
\hline Nicaragua & 5 & 7 & 4 & 7 & 0 & 0 & 0.26 \\
\hline Niger & 0 & 0 & 0 & 0 & 0 & 0 & NA \\
\hline Nigeria & 2 & 23 & 0 & 8 & 0 & 0 & 0.55 \\
\hline Norway & 103 & 35 & 51 & 54 & 0 & 0 & 0.29 \\
\hline Oman & 5 & 1 & 2 & 11 & 0 & 0 & 0.42 \\
\hline Pakistan & 34 & 56 & 172 & 75 & 0 & 0 & 0.35 \\
\hline
\end{tabular}


Table 1. Continued

\begin{tabular}{|c|c|c|c|c|c|c|c|}
\hline Country & $\mathrm{BRC}$ & $\begin{array}{l}\text { FSSC } \\
22000\end{array}$ & GlobalGAP & $\begin{array}{l}\text { ISO } \\
22000\end{array}$ & PrimusGFS & SQF & $\begin{array}{l}\text { HHI across } \\
\text { Standards }\end{array}$ \\
\hline Panama & 2 & 4 & 41 & 2 & 0 & 0 & 0.71 \\
\hline Paraguay & 5 & 4 & 0 & 3 & 0 & 0 & 0.35 \\
\hline Peru & 97 & 27 & 6,462 & 8 & 0 & 14 & 0.96 \\
\hline Philippines & 36 & 76 & 9 & 63 & 0 & 0 & 0.33 \\
\hline Poland & 796 & 110 & 3,163 & 640 & 0 & 0 & 0.5 \\
\hline Portugal & 130 & 22 & 913 & 192 & 0 & 0 & 0.56 \\
\hline Qatar & 0 & 1 & 0 & 11 & 0 & 0 & 0.85 \\
\hline Romania & 51 & 153 & 66 & 1,014 & 0 & 0 & 0.64 \\
\hline Russian Federation & 74 & 263 & 1 & 279 & 0 & 0 & 0.4 \\
\hline Rwanda & 0 & 1 & 0 & 0 & 0 & 0 & 1 \\
\hline Samoa & 0 & 1 & 0 & 0 & 0 & 0 & 1 \\
\hline $\begin{array}{l}\text { São Tomé and } \\
\text { Príncipe }\end{array}$ & 0 & 0 & 0 & 0 & 0 & 0 & NA \\
\hline Saudi Arabia & 31 & 15 & 6 & 138 & 0 & 0 & 0.56 \\
\hline Senegal & 4 & 1 & 290 & 0 & 0 & 0 & 0.97 \\
\hline Singapore & 12 & 28 & 0 & 100 & 0 & 1 & 0.55 \\
\hline Slovakia & 36 & 25 & 22 & 123 & 0 & 0 & 0.41 \\
\hline Slovenia & 10 & 9 & 50 & 19 & 0 & 0 & 0.39 \\
\hline Solomon Islands & 1 & 0 & 0 & 0 & 0 & 0 & 1 \\
\hline South Africa & 224 & 259 & 2,050 & 260 & 0 & 0 & 0.56 \\
\hline South Korea & 6 & 132 & 292 & 127 & 0 & 41 & 0.34 \\
\hline Spain & 1,551 & 164 & 32,149 & 525 & 0 & 0 & 0.88 \\
\hline Sri Lanka & 51 & 35 & 5 & 301 & 0 & 0 & 0.61 \\
\hline Sweden & 215 & 129 & 17 & 56 & 0 & 0 & 0.38 \\
\hline Switzerland & 223 & 183 & 59 & 224 & 0 & 0 & 0.29 \\
\hline Tanzania & 7 & 6 & 212 & 5 & 0 & 0 & 0.85 \\
\hline Thailand & 426 & 114 & 107 & 278 & 0 & 14 & 0.32 \\
\hline Togo & 0 & 0 & 0 & 1 & 0 & 0 & 1 \\
\hline Tunisia & 9 & 18 & 184 & 98 & 0 & 0 & 0.46 \\
\hline Turkey & 537 & 147 & 2,133 & 733 & 0 & 0 & 0.43 \\
\hline Uganda & 2 & 3 & 13 & 15 & 0 & 0 & 0.37 \\
\hline Ukraine & 9 & 98 & 3 & 173 & 0 & 0 & 0.49 \\
\hline United Kingdom & 3,786 & 76 & 80 & 82 & 0 & 0 & 0.89 \\
\hline United States & 1,833 & 951 & 1,611 & 157 & 8,720 & 4,354 & 0.33 \\
\hline Uruguay & 27 & 11 & 40 & 18 & 0 & 0 & 0.3 \\
\hline Venezuela & 0 & 13 & 0 & 5 & 0 & 1 & 0.54 \\
\hline Vietnam & 243 & 47 & 323 & 311 & 0 & 0 & 0.31 \\
\hline Zambia & 1 & 5 & 3 & 7 & 0 & 0 & 0.33 \\
\hline Zimbabwe & 5 & 6 & 48 & 8 & 0 & 0 & 0.54 \\
\hline $\begin{array}{r}\text { HHI across } \\
\text { countries }\end{array}$ & 0.07 & 0.04 & 0.10 & 0.16 & 0.58 & 0.49 & \\
\hline
\end{tabular}

Notes: $\mathrm{HHI}$ across standards is the Herfindal concentration index across the six standards for a country (i.e., horizontal calculation in the table). HHI across countries is the Herfindal concentration index across all countries for a standard (i.e., vertical calculation in the table). BRC, British Retail Consortium Food Standard; FSSC 22000, Food Safety System Certification 22000; GlobalGAP, Global Good Agricultural Practices; IFS, International Featured Standards Foods; ISO 22000, International Organization for Standardization 22000; NA, not available; PrimusGFS, developed by PrimusLab as a Global Food Safety Initiative variant; SQF, Safe Quality Food. 
standard or different standards, adding up the numbers for a country does not yield the number of certified producers. Table 1 shows that for a given country, the number of certified sites to the farming exclusive GlobalGAP standard is normally several times larger than that to any other standard. There is also a huge difference in the numbers of certified sites across countries, with such gaps being particularly large between developing and developed countries. In the last column of the table, we also reported the Herfindal concentration index across the six standards (HHI across standards) for a country (i.e., horizontal calculation in the table). This HHI measures the distribution of standards within a country. Similarly, we report in the last row the HHI across all countries for a standard (i.e., vertical calculation in the table, HHI across countries), measuring the distribution of sites across countries for a standard. For example, the HHI across standards is 0.62 and 0.33 for China and the United States, respectively. These numbers reflect the fact that for China, ISO 22000 accounted for most of the certified sites, and for the United States, two U.S.-based standards (PrimusGFS and SQF) led the certification numbers together. The HHI across countries also indicates that the two U.S.-based standards are much more concentrated (HHI equals 0.58 and 0.49 ) than the rest of the four standards (HHI equals 0.07, 0.04, 0.10 , and 0.16 ).

In Table 2, we included the top 10 countries for each standard. We also plotted in Figure 1 the distribution of certified sites, with one world map for each standard. Several patterns emerge from the data by looking at the two tables and the map. First, standards have very different geographic coverage, with some primarily being adopted by their own and surrounding countries, whereas some others enjoying much wider international adoption. For example, almost all of the top three countries adopting the two U.S.-based standards are in North America. Similarly, United Kingdom is the top country adopting the BRC standard, which is a British standard. The other three standards are also Europe-based standards as the headquarters of FSSC 22000, GlobalGAP, and ISO 22000 are located in Netherlands, France, and Switzerland, respectively. ${ }^{5}$ However, FSSC 22000 and ISO 22000 are widely adopted by countries outside Europe such as the United States, China, and India. Overall, the figures show that European countries had the highest numbers of certificates for the four European standards, whereas Africa and South America tended to have the lowest numbers for any standard. Second, producers within the same country can have a disperse attraction for different standards. This is evident by observing many countries, such as the United States, China, India, Poland, and Japan, that appear in the top 10 lists for multiple standards in the table. Third, many countries, especially countries with limited numbers of certified sites, tend to focus on one standard. This is the case for countries such as Algeria, Kuwait, and Zimbabwe.

5 IFS is a Germany-based standard. 


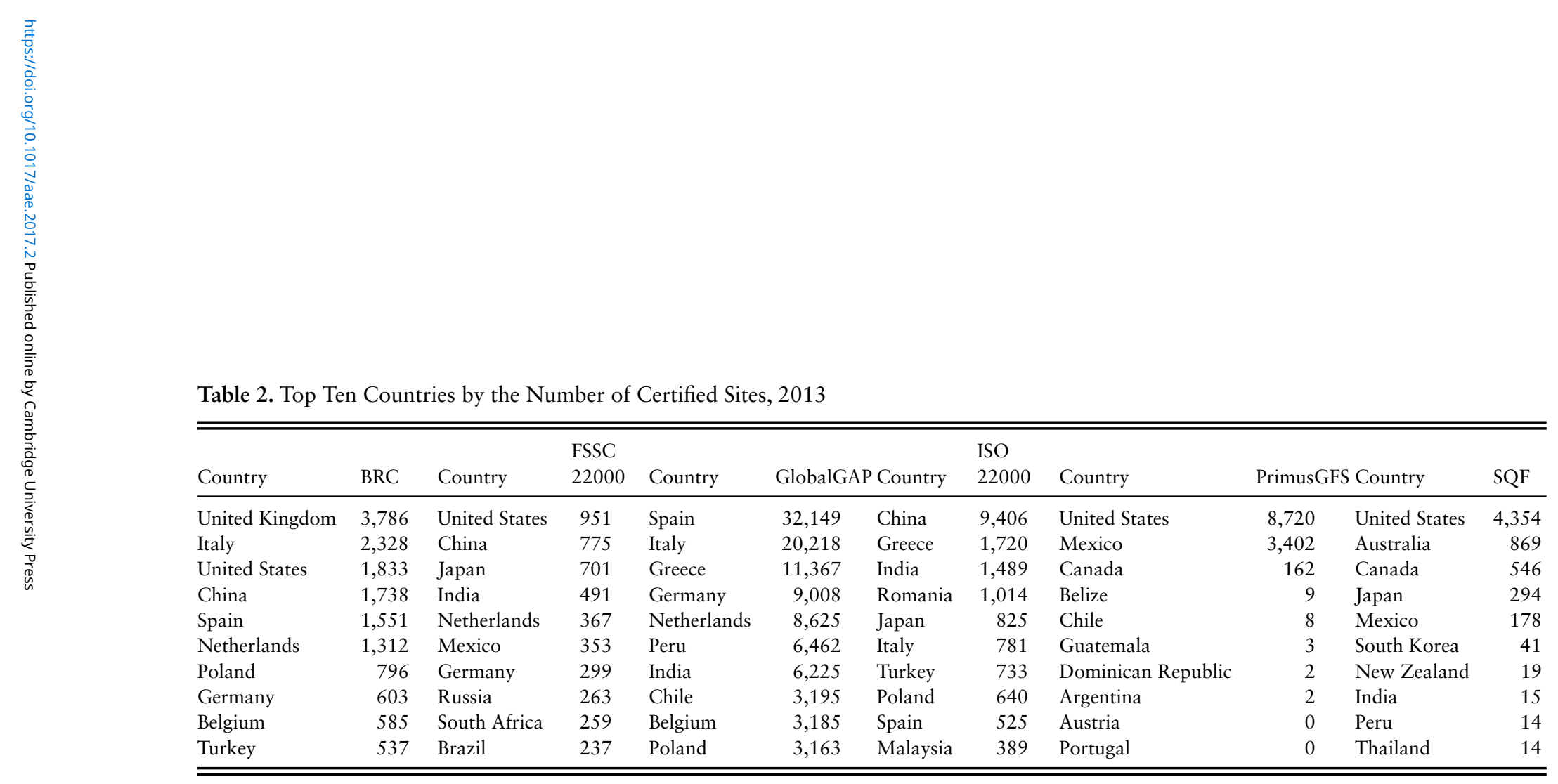

Note: BRC, British Retail Consortium Food Standard; FSSC 22000, Food Safety System Certification 22000; GlobalGAP, Global Good Agricultural Practices; IFS, International Featured Standards Foods; ISO 22000, International Organization for Standardization 22000; PrimusGFS, developed by PrimusLab as a Global Food Safety Initiative variant; SQF, Safe Quality Food. 

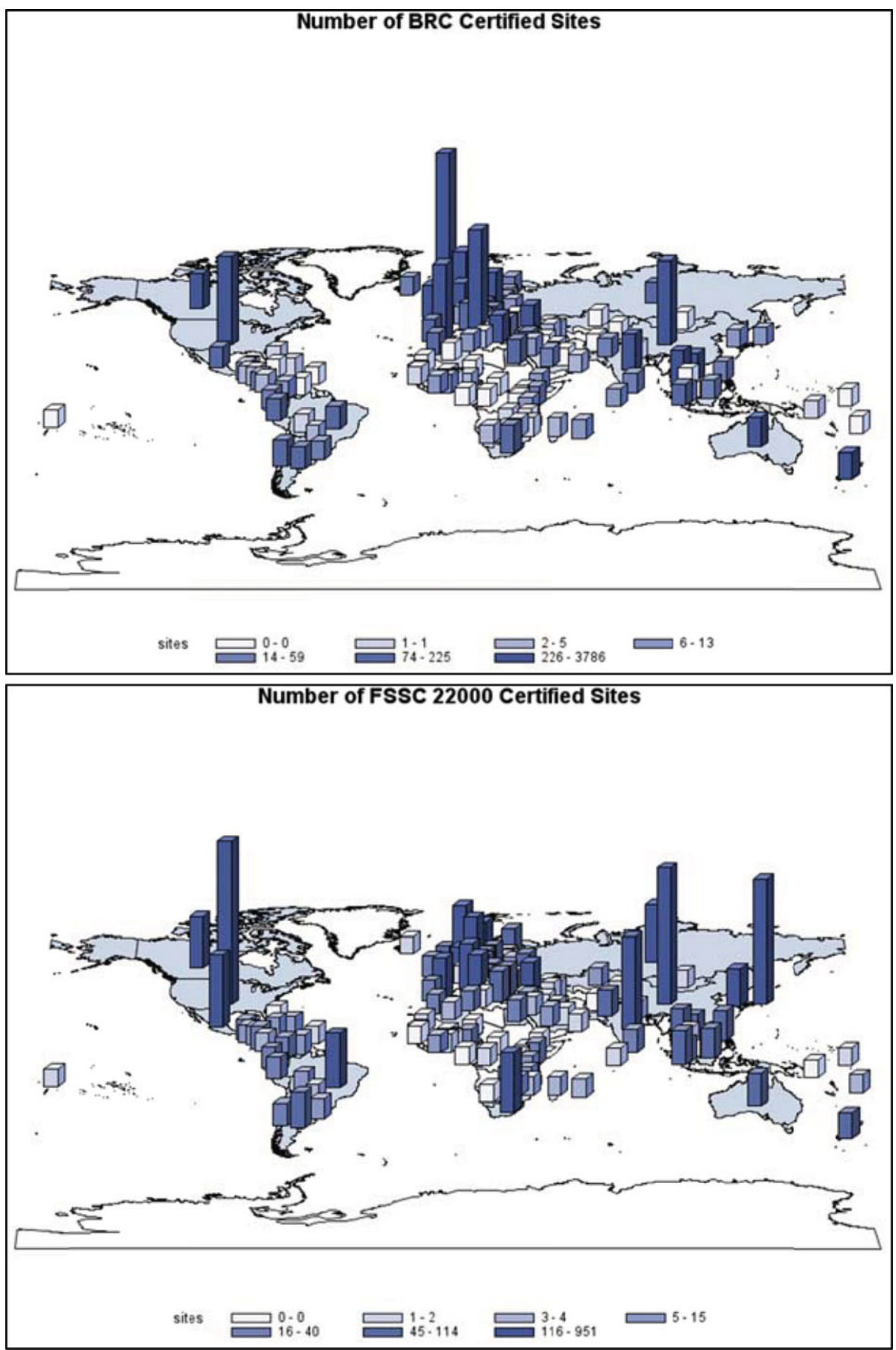

Figure 1. Maps of Certified Sites by Country and Standard (year $=2013$; BRC, British Retail Consortium Food Standard; FSSC 22000, Food Safety System Certification 22000; GlobalGAP, Global Good Agricultural Practices; ISO 22000, International Organization for Standardization 22000; PrimusGFS, developed by PrimusLab as a Global Food Safety Initiative variant; SQF, Safe Quality Food) 

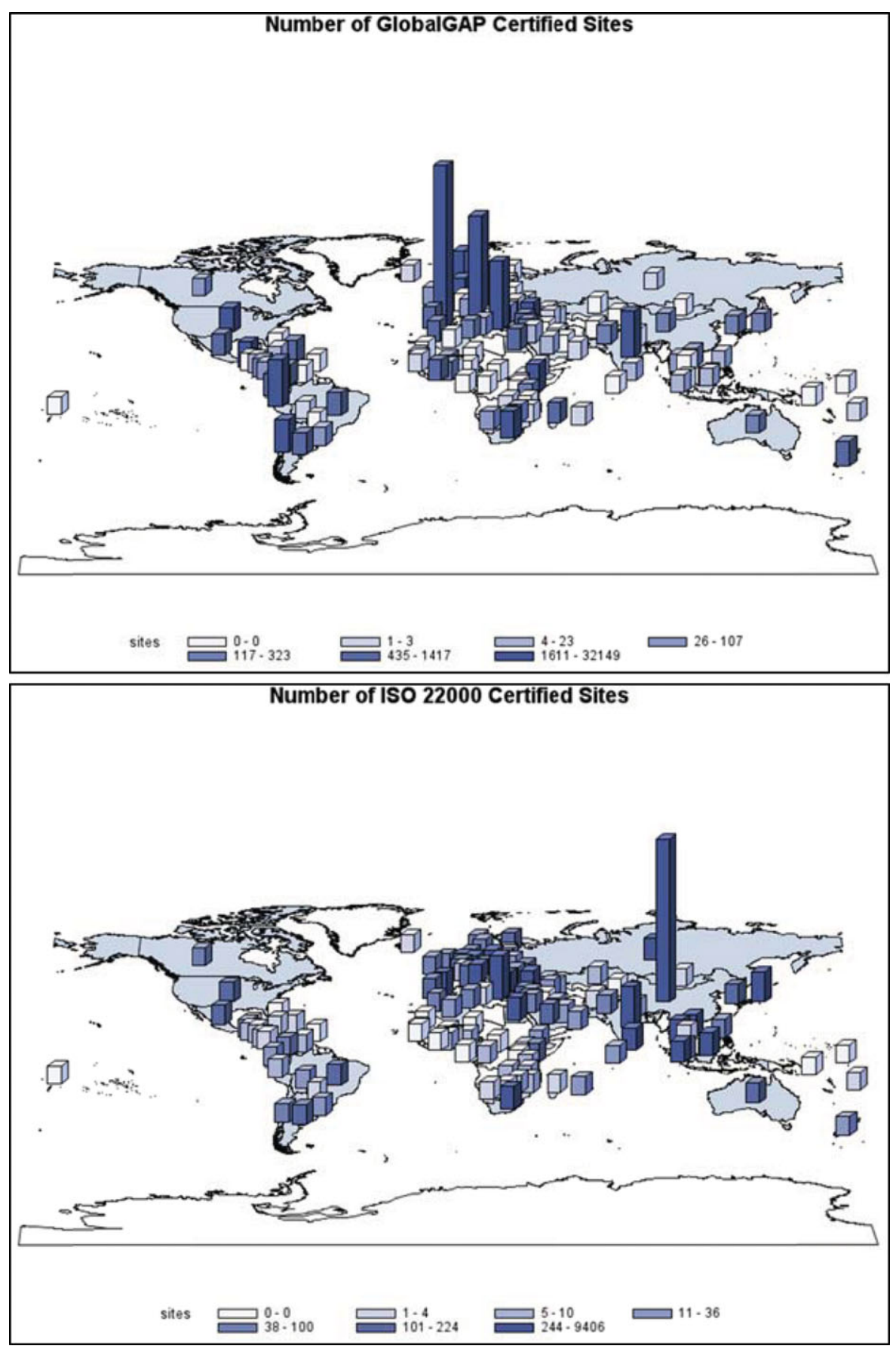

Figure 1. Continued 

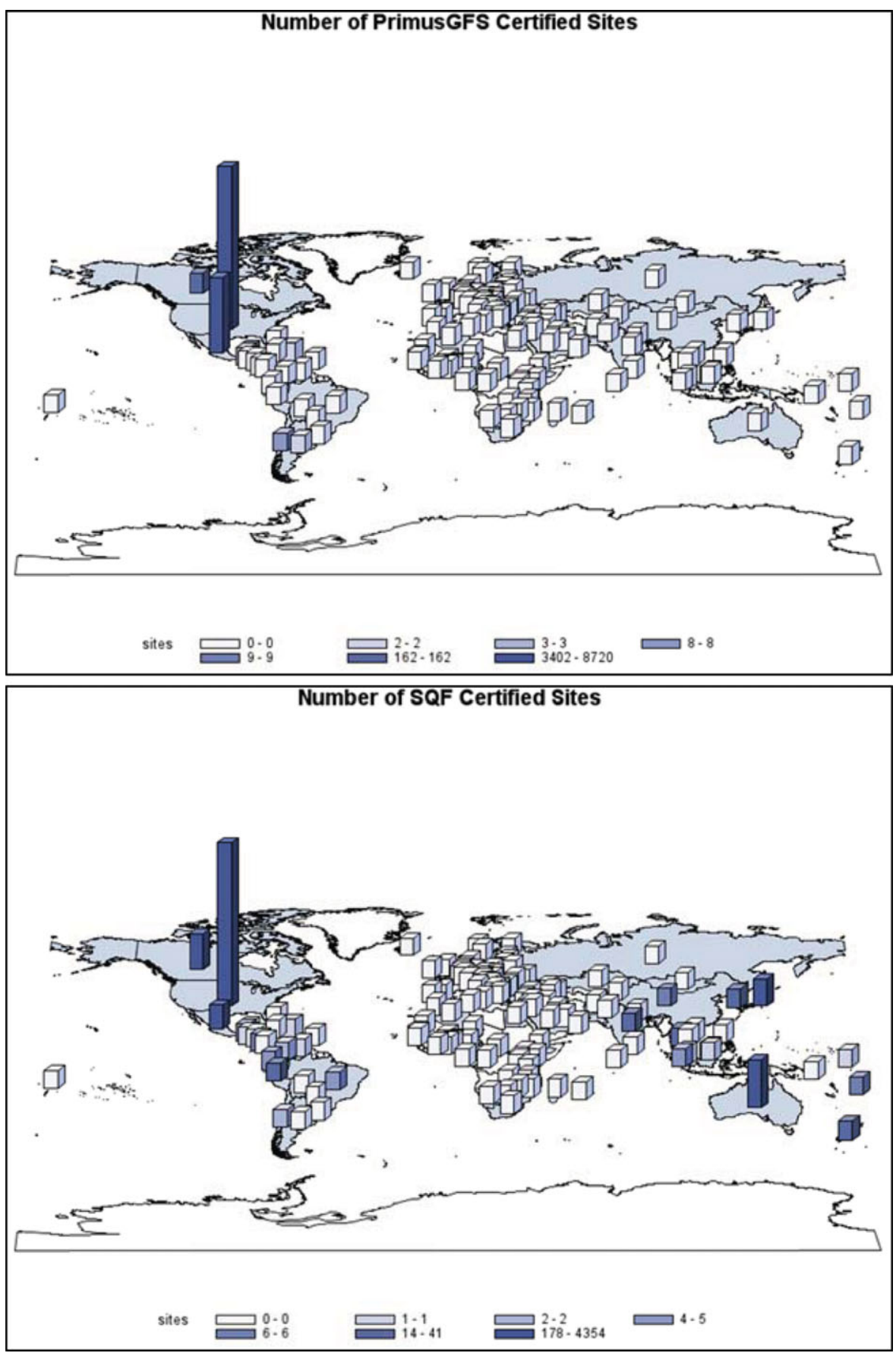

Figure 1. Continued 
One might wonder what reasons could explain the lack of certified sites and what impact this might have on a country's ability to export. The first question becomes the focus of this article. Potential reasons include economic constraints such as less economic development, lack of a middle class that accounts for domestic demand for certification, access barrier to certifiers (note that standards are freely available for downloading), and lack of demand for traded products. Exporting a small share of food exports or exporting a small share of food exports to countries with a high demand for safety certification (generally developed countries) can cause a lack of demand for certification. As to the second question, a lack of certified sites may make a country's food exports less attractive to developed countries.

The rest of the article is organized as follows: Sections 2 and 3 describe the model and data we used, respectively. Section 4 presents the results, and Section 5 contains some concluding remarks.

\section{A Model of Certification Adoption}

We model each country's certified sites to a standard as the dependent variable (the numbers presented in Table 1). Two commonly used models for count data, the Poisson model and the negative binomial model, suit our needs well. However, one major shortcoming of the Poisson model is that it assumes the variance of the dependent variable equals its mean. The negative binomial model subsumes the Poisson model, does not impose the equidispersion assumption, and allows for a test of the assumption (Greene 2012). Therefore, following Herzfeld, Drescher, and Grebitus's (2011) study, we adopt a negative binomial model and will conduct a test on the equidispersion assumption. The summary statistics in Table 3 show a mean of 162.44 and a standard deviation of 479.64 for the dependent variable, providing some justification for our choice.

Our model is specified as follows:

$$
E\left(y_{i c} \mid x_{i c}\right)=\exp \left(x^{\prime} \beta+e_{i c}\right)
$$

where $i(i=1, \ldots, 6)$ indexes the six standards in Table $1, c$ indexes country, $y_{i c}$ is the number of sites in country $c$ certified to standard $i, x^{\prime} \beta$ are explanatory variables to be defined, and $e_{i c}$ is the error term. The probability mass function is

$\operatorname{Pr}\left(Y_{i c}=y_{i c} \mid x_{i c}, \alpha\right)=\frac{\Gamma\left(\alpha^{-1}+y_{i c}\right)}{\Gamma\left(\alpha^{-1}\right) y_{i c} !}\left(\frac{\alpha^{-1}}{\alpha^{-1}+\exp \left(x^{\prime} \beta\right)}\right)^{\alpha^{-1}}\left(\frac{\exp \left(x^{\prime} \beta\right)}{\alpha^{-1}+\exp \left(x^{\prime} \beta\right)}\right)^{y_{i c}}$,

where $\alpha$, the overdispersion parameter to be estimated, serves as a formal test of overdispersion in the data. The conditional variance is

$$
\operatorname{Var}\left(y_{i c} \mid x_{i c}\right)=\exp \left(x^{\prime} \beta\right)\left[1+\alpha \exp \left(x^{\prime} \beta\right)\right] \text {. }
$$


Table 3. Definitions and Summary Statistics of Variables

\begin{tabular}{|c|c|c|c|c|c|c|}
\hline Variables & Definition & Source & Mean & Standard Deviation & Minimum & Maximum \\
\hline \multirow[t]{6}{*}{$y$} & Number of sites certified to BRC & Standard's website & 162.44 & 479.64 & 0 & $3,786.00$ \\
\hline & $\begin{array}{l}\text { Number of sites certified to FSSC } \\
22000\end{array}$ & Standard's website & 63.98 & 141.91 & 0 & 951.00 \\
\hline & $\begin{array}{l}\text { Number of sites certified to } \\
\text { GlobalGAP }\end{array}$ & $\begin{array}{l}\text { Communications with } \\
\text { GlobalGAP }\end{array}$ & $1,025.25$ & $3,659.99$ & 0 & $32,149.00$ \\
\hline & $\begin{array}{l}\text { Number of sites certified to ISO } \\
22000\end{array}$ & $\begin{array}{l}\text { ISO Survey of } \\
\text { Certifications }\end{array}$ & 191.97 & 850.13 & 0 & $9,406.00$ \\
\hline & $\begin{array}{l}\text { Number of sites certified to } \\
\text { PrimusGFS }\end{array}$ & Standard's website & 93.95 & 815.63 & 0 & $8,720.00$ \\
\hline & Number of sites certified to SQF & Standard's website & 48.78 & 390.46 & 0 & $4,354.00$ \\
\hline \multirow[t]{6}{*}{$C B$} & Number of BRC certification bodies & $\begin{array}{l}\text { Standard's website; } \\
\text { web search }\end{array}$ & 3.40 & 5.56 & 0 & 30.00 \\
\hline & Number of FSSC certification bodies & $\begin{array}{l}\text { Standard's website; } \\
\text { web search }\end{array}$ & 0.79 & 1.90 & 0 & 10.00 \\
\hline & $\begin{array}{l}\text { Number of GlobalGAP certification } \\
\text { bodies }\end{array}$ & $\begin{array}{l}\text { Standard's website; } \\
\text { web search }\end{array}$ & 0.98 & 2.79 & 0 & 19.00 \\
\hline & $\begin{array}{l}\text { Number of ISO } 22000 \text { certification } \\
\text { bodies }\end{array}$ & $\begin{array}{l}\text { Standard's website; } \\
\text { web search }\end{array}$ & 1.28 & 3.12 & 0 & 21.00 \\
\hline & $\begin{array}{l}\text { Number of PrimusGFS certification } \\
\text { bodies }\end{array}$ & $\begin{array}{l}\text { Standard's website; } \\
\text { web search }\end{array}$ & 0.05 & 0.44 & 0 & 5.00 \\
\hline & Number of SQF certification bodies & $\begin{array}{l}\text { Standard's website; } \\
\text { web search }\end{array}$ & 0.06 & 0.48 & 0 & 5.00 \\
\hline Dist & $\begin{array}{l}\text { Distance to standard holder } \\
(1,000 \mathrm{~km})\end{array}$ & CEPII & 6.80 & 4.12 & 0.08 & 19.26 \\
\hline$G D P$ & Per capita GDP $(\$ 1,000,2005$ US\$) & $\begin{array}{l}\text { World Development } \\
\text { Index }\end{array}$ & 12.41 & 16.63 & 0.16 & 79.53 \\
\hline$E x p \_E U$ & $\begin{array}{l}\text { Proportion of food exports to } \\
\text { European Union }\end{array}$ & UN Comtrade & 0.33 & 0.28 & 0 & 0.97 \\
\hline$E x p \_N A$ & $\begin{array}{l}\text { Proportion of food exports to North } \\
\text { America }\end{array}$ & UN Comtrade & 0.11 & 0.18 & 0 & 0.84 \\
\hline
\end{tabular}


Table 3. Continued

\begin{tabular}{|c|c|c|c|c|c|c|}
\hline Variables & Definition & Source & Mean & Standard Deviation & Minimum & Maximum \\
\hline Exp_SA & $\begin{array}{l}\text { Proportion of food exports to South } \\
\text { America }\end{array}$ & UN Comtrade & 0.03 & 0.09 & 0 & 0.73 \\
\hline Exp_AS & Proportion of food exports to Asia & UN Comtrade & 0.29 & 0.28 & 0 & 1.00 \\
\hline Exp_AF & Proportion of food exports to Africa & UN Comtrade & 0.12 & 0.19 & 0 & 0.99 \\
\hline Exp_wld & Total food exports (million US\$) & UN Comtrade & 7.75 & 15.47 & 0 & 103.07 \\
\hline Exp_meat & $\begin{array}{l}\text { Proportion of food exports that is } \\
\text { meat }\end{array}$ & UN Comtrade & 0.07 & 0.11 & 0 & 0.71 \\
\hline Exp_fish & Proportion of food exports that is fish & UN Comtrade & 0.16 & 0.23 & 0 & 0.99 \\
\hline Exp_veggie & $\begin{array}{l}\text { Proportion of food exports that is } \\
\text { vegetables or fruits }\end{array}$ & UN Comtrade & 0.22 & 0.21 & 0 & 0.96 \\
\hline Urban & $\begin{array}{l}\text { Proportion of populating living in } \\
\text { urban areas }\end{array}$ & $\begin{array}{l}\text { World Development } \\
\text { Index }\end{array}$ & 0.60 & 0.23 & 0.11 & 1 \\
\hline Agland & Agricultural land (million $\mathrm{km}^{2}$ ) & $\begin{array}{l}\text { World Development } \\
\text { Index }\end{array}$ & 0.32 & 0.78 & 0.00001 & 5.15 \\
\hline Language & $\begin{array}{l}\text { Dummy variable for sharing a } \\
\text { common language }\end{array}$ & CEPII & 0.21 & 0.41 & 0 & 1.00 \\
\hline Colony & Dummy variable for being colonized & CEPII & 0.09 & 0.28 & 0 & 1.00 \\
\hline Contig & Dummy variable for sharing border & CEPII & 0.02 & 0.14 & 0 & 1.00 \\
\hline Landlocked & $\begin{array}{l}\text { Dummy variable for being a } \\
\text { landlocked country }\end{array}$ & CEPII & 0.21 & 0.40 & 0 & 1.00 \\
\hline
\end{tabular}

Note: BRC, British Retail Consortium Food Standard; CEPII, Centre d'Etudes Prospectives et d'Informations Internationales; FSSC 22000, Food Safety System Certification 22000; GlobalGAP, Global Good Agricultural Practices; IFS, International Featured Standards Foods; ISO 22000, International Organization for Standardization 22000; PrimusGFS, developed by PrimusLab as a Global Food Safety Initiative variant; SQF, Safe Quality Food. 
We specify a country's adoption of certification in the following manner, where $\beta_{i}^{s}$ represents parameters, and vector is denoted with bold:

$$
\begin{aligned}
x^{\prime} \beta= & \beta_{0}+\beta_{1} C_{i c}+\beta_{2} \text { Dist }_{i c}+\beta_{3} G D P_{c}+\beta_{4} \text { Exp_wld }_{c}+\boldsymbol{\beta}_{5} \text { Exp_Destination }_{c} \\
& +\boldsymbol{\beta}_{6} \text { Exp_Product }_{c}+\beta_{7} \text { Urban }_{c}+\beta_{8} \text { Agland }_{c}+\beta_{9} \text { Language }_{i c} \\
& +\beta_{10} \text { Colony }_{i c}+\beta_{11} \text { Contig }_{i c}+\beta_{12} \text { Landlocked }_{c}+\boldsymbol{\beta}_{13} \text { Dummy }_{i c} .
\end{aligned}
$$

We included three sets of explanatory variables in the model, including core variables, trade-related variables, and other control variables such as language and colonial relationship. The first set is three core variables we hypothesize to determine the adoption of certification: the number of certification bodies in country $c$ that are accredited to certify to standard $i\left(C B_{i c}\right)$, the capital-tocapital distance between country $c$ and the home country of standard $i\left(D_{i s t} i_{c}\right)$, and the per capita gross domestic product of country $c\left(G D P_{c}\right)$. The number of certification bodies is counted at the headquarters level. For example, two BRC-accredited certification bodies with 5 and 25 respective offices in India would count as two in our data for India for BRC adoption. Many multinational certification bodies certify to food safety standards as well as to other nonfoodrelated standards. Having multiple offices in a country is common, with some even reaching more than 100 . It is impossible to identify which office offers food safety certification (some of them are technical labs that conduct testing). Counting at the headquarters level makes the data much less noisy to the aforementioned complications.

The second set of variables is related to trade. The variable Exp_wld is a country's total food exports $(\$)$ to the world. The vector Exp_Destination includes five variables capturing food export destinations: $E x p \_E U, E x p \_N A$, $E x p \_S A, E x p \_A S$, and $E x p \_A F$. The five variables represent the proportions of a country's food exports to the European Union, North America, South America, Asia, and Africa. These six variables combined capture the impacts of the food export size and the destination region on certification adoption. One motivation for including trade in our model is because private food safety standards are strictly business-to-business standards. That is, institutional buyers such as retailers and importers will observe the certification status of suppliers and use this as a criterion to select suppliers, which can provide producers an incentive to certify. In most cases, consumers will not be able to tell whether a product is certified because food safety certification is normally not labeled on product packages, unlike other product attributes such as organic, non-GMO, or

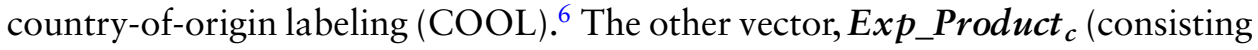
of Exp_meat, Exp_fish, and Exp_veggie), represents the proportions of a

\footnotetext{
6 Some attributes are required by governments to be posted on the package, such as the COOL in some countries. However, the COOL requirement for beef and pork products in the United States was ended in 2015 .
} 
country's food exports that are meat (meat and meat preparations), fish (fish, crustaceans, mollusks, and aquatic invertebrates), and vegetables and fruits. We include the export shares of meat, fish, and vegetables and fruits because these products are viewed as more vulnerable to contamination and diseases than other products such as grains and oil. ${ }^{7}$ A higher proportion of food exports in meat, fish, or vegetables and fruits might have a higher demand for food safety certification.

Third, building on the two most related studies, Neumayer and Perkins's (2005) work on the cross-national adoption of ISO 9000 certification and Herzfeld, Drescher, and Grebitus's (2011) study of cross-national adoption of GlobalGAP and BRC standards, we include a country's agricultural land size (Agland), a dummy variable for sharing a common language with the standard holder's country, a dummy variable for being colonized by the standard holder's country, a dummy variable for sharing a border with the standard holder's country, and another dummy variable for being a landlocked country. These variables are intended to control for a country's scope of agriculture and aquaculture (land and sea fishing endowment), closeness, and adjacency with the standard holder's country. For example, being a landlocked country (no domestic access to a seaport and no endowment in sea fishing) is likely to indicate having limited trading partners and less economic development, with some of these effects also being captured by our use of GDP and food export. On the other hand, being a landlocked country also can provide protection from cheap food imports and result in a more robust local food system and less use of food safety certification. Overall, we expect the impact of being landlocked to be negative. Herzfeld, Drescher, and Grebitus (2011) also tried to control for a country's infrastructure by including a measure of road density. However, this variable was not found to be statistically significant. We also tried including another variable, the number of Internet users per 100 people, following Neumayer and Perkins's (2005) argument that communications matter. However, because the number of Internet users is highly correlated with GDP, with a correlation of 0.77 , the impact of GDP is not significant when Internet users are included. Finally, we also included the proportion of the population living in urban area to reflect the domestic demand from the middle class for food safety certification. ${ }^{8}$

We have data for 131 countries for the six standards. To increase the predictive power, we pooled the country over the standards so we have a total sample size of 786 (in the sense of panel data, country is a cross-sectional observation while standard is treated as time here). The variable Dummy $i c$ in equation (4) is a vector of dummy variables controlling for standard and the continent where country $i$

7 We thank an anonymous review for making this suggestion.

8 Note that for our model, $C B_{i c}$ is a supply-side variable, whereas most other variables such as $G D P_{c}$ and export variables are demand-side variables. 
is located. ${ }^{9}$ In Section 4.2, we will examine whether our results are robust to various ways of grouping standards.

\section{Data Description}

We combined data from different sources. Table 3 presents the definitions and summary statistics for the variables used. We present the data for certified sites and certification bodies by each standard and present the rest of the data at the aggregate level to preserve space. Data are for the year 2013. For the dependent variable, we collected the data from personal communications with GlobalGAP, ISO Survey of Certifications (ISO, 2013), and from standard holders' websites for the other four standards. We obtained the number of accredited certification bodies in each country mainly from the standard holders' websites augmented by our own web search.

Table 3 shows that on average, GlobalGAP was the most adopted standard, followed by a distant second of ISO 22000 and third of BRC. SQF was the least adopted standard. Note that although the six standards cover all food products, their coverages at the production stage vary. GlobalGAP is primarily a farming standard that does not cover the food manufacturing or processing stage. BRC, FSSC 22000, and ISO 22000 are standards for food manufacturing and processing (see the Global Food Safety Initiative, 2015). PrimusGFS and SQF cover both farming and food manufacturing/processing. Therefore, the rank of farming standards in terms of adoption is GlobalGAP, PrimusGFS, and SQF. The rank of manufacturing and processing standards is ISO 22000, BRC, PrimusGFS, FSSC 22000, and SQF.

Data on GDP, urban population, and agricultural land came from the World Bank's (2013) World Development Indicators. Data on food exports were obtained from the United Nations Commodity Trade Statistics Database, known as UN Comtrade (2015). UN Comtrade contains detailed import and export statistics reported by statistical authorities in approximately 200 countries or areas. The food exports are exports reported by the exporting country under the Standard International Trade Classification (as reported) code 1, which is food and live animals. This code covers live animals, meat, dairy products and eggs, seafood, cereals, vegetables and fruits, sugar products, coffee and tea, and animal feeds and does not include beverages or tobacco products. Finally, data on distance, colony, contiguousness, common language, and landlocked status were from Mayer and Zignago (2011; also known as the CEPII [Centre d'Etudes Prospectives et d'Informations Internationales] GeoDist data). After merging the data, we have observations for 131 countries for all the six standards.

9 Using country dummies will exhaust the degrees of freedom. Using the continent dummy is an effective alternative, while controlling for continent fixed effects. 


\section{Results}

\subsection{Main Specification}

We estimated the negative binomial model using STATA version 13. Table 4 displays the results of our model. We estimated four variations of the model by adding one set of variables at a time, where all specifications include the dummy variables controlling for standards and continents. In column (1), we present a base specification that includes our three core variables (certification bodies, distance, and GDP). ${ }^{10}$ The effects are all statistically significant (at the $5 \%$ default level or better) with the expected signs. The number of domestic certification bodies and per capita GDP both have a positive effect on the adoption of food safety certification. Such findings may help explain part of the wide adoption of GlobalGAP. GlobalGAP has 153 certification bodies worldwide, the largest of the standards studied here. In comparison, BRC has 88 certification bodies worldwide. On the other hand, we found that the effect of distance to standard holder has a negative impact on certification adoption. That is, countries prefer adopting standards that are based in nearby countries. One might wonder if the result is driven by cheaper input (less travel cost to invite certifiers from the home country and less cost for producers to learn about the standard) or a higher volume of exports to nearby countries. Because we specifically control for the latter, the result is likely driven by the former reason. This result indicates that geography helps create product differentiations and provides market power to the standard holders (e.g., PrimusGFS and SQF's dominance in North America and GlobalGAP's success in Europe).

In column (2) we added total food exports plus the breakdown by export destinations. The three core variables remain statistically significant. We found total food exports had a positive impact on certification adoption. Such a result is consistent with the view that higher food exports can create larger demand for food safety certification. On one hand, importer requirements may force countries to use certifiers. On the other hand, exporters may use certification to create a competitive advantage for certain agricultural products. As to the export destinations, this specification shows that higher proportions of food exports to North America or to Asia increased the demand for certification. Surprisingly, the proportion of food exports to Europe was not found to be statistically significant. This seems at odds with previous studies that highlighted the importance of international private retailers (e.g., in Europe) in driving the adoption of certification in Africa, Asia, and Latin America (e.g., Reardon et al., 2003). Several reasons could contribute to this finding. First, continent fixed effects may already have picked up some of the regional variations in certification numbers. Second, some U.S. retailers (e.g., Wal-Mart in 2008) were the first to

10 All the continent fixed effects and four of the five dummy variables controlling for standards are statistically significant, highlighting the importance of controlling for these effects. 
Table 4. Estimation Results using the Negative Binomial Model

\begin{tabular}{|c|c|c|c|c|c|}
\hline $\begin{array}{l}\text { Dependent Variable: } \\
\text { Number of Certified } \\
\text { Sites }\end{array}$ & $\begin{array}{l}(1) \text { Core } \\
\text { Variables }\end{array}$ & $\begin{array}{l}\text { (2) Trade } \\
\text { Destina- } \\
\text { tions }\end{array}$ & $\begin{array}{l}\text { (3) Trade } \\
\text { Products }\end{array}$ & $\begin{array}{l}\text { (4) Both } \\
\text { Trade } \\
\text { Effects }\end{array}$ & $\begin{array}{l}\text { (5) Full } \\
\text { Control } \\
\text { Variables }\end{array}$ \\
\hline $\begin{array}{l}\text { Number of } \\
\text { certification bodies }\end{array}$ & $\begin{array}{l}0.519^{* * *} \\
(0.06)\end{array}$ & $\begin{array}{l}0.315^{* * *} \\
(0.05)\end{array}$ & $\begin{array}{l}0.295^{* * *} \\
(0.06)\end{array}$ & $\begin{array}{l}0.296^{* * *} \\
(0.05)\end{array}$ & $\begin{array}{l}0.285^{* * *} \\
(0.05)\end{array}$ \\
\hline $\begin{array}{l}\text { Distance to standard } \\
\text { holder's country } \\
(1,000 \mathrm{~km})\end{array}$ & $\begin{array}{c}-0.302^{* * *} \\
(0.04)\end{array}$ & $\begin{array}{c}-0.138^{* * *} \\
(0.03)\end{array}$ & $\begin{array}{c}-0.229^{* * *} \\
(0.04)\end{array}$ & $\begin{array}{c}-0.127^{* * *} \\
(0.04)\end{array}$ & $\begin{array}{c}-0.112^{* * *} \\
(0.04)\end{array}$ \\
\hline $\begin{array}{l}\text { Per capita GDP } \\
\qquad(\$ 1,000)\end{array}$ & $\begin{array}{l}0.015^{* *} \\
(0.01)\end{array}$ & $\begin{array}{l}0.015^{* *} \\
(0.01)\end{array}$ & $\begin{array}{l}0.024^{* * *} \\
(0.01)\end{array}$ & $\begin{array}{l}0.016^{* *} \\
(0.01)\end{array}$ & $\begin{array}{c}0.002 \\
(0.01)\end{array}$ \\
\hline $\begin{array}{l}\text { Proportion of food } \\
\text { exports to EU }\end{array}$ & & $\begin{array}{c}0.25 \\
(0.78)\end{array}$ & & $\begin{array}{r}-0.065 \\
(0.80)\end{array}$ & $\begin{array}{c}0.203 \\
(0.79)\end{array}$ \\
\hline $\begin{array}{l}\text { Proportion of food } \\
\text { exports to NA }\end{array}$ & & $\begin{array}{l}9.290^{* * *} \\
(1.14)\end{array}$ & & $\begin{array}{l}8.732^{* * *} \\
(1.16)\end{array}$ & $\begin{array}{l}5.429^{* * *} \\
(1.44)\end{array}$ \\
\hline $\begin{array}{l}\text { Proportion of food } \\
\text { exports to SA }\end{array}$ & & $\begin{array}{l}3.579^{*} \\
(1.96)\end{array}$ & & $\begin{array}{l}3.751^{*} \\
(2.00)\end{array}$ & $\begin{array}{c}2.716 \\
(1.90)\end{array}$ \\
\hline $\begin{array}{l}\text { Proportion of food } \\
\text { exports to Asia }\end{array}$ & & $\begin{array}{l}2.488^{* * *} \\
(0.83)\end{array}$ & & $\begin{array}{l}2.243^{* *} \\
(0.92)\end{array}$ & $\begin{array}{c}0.986 \\
(0.95)\end{array}$ \\
\hline $\begin{array}{l}\text { Proportion of food } \\
\text { exports to Africa }\end{array}$ & & $\begin{array}{r}0.649 \\
(0.93)\end{array}$ & & $\begin{array}{c}0.215 \\
(0.97)\end{array}$ & $\begin{array}{r}-0.061 \\
(0.93)\end{array}$ \\
\hline $\begin{array}{l}\text { Total food exports } \\
\qquad \text { (\$1 million) }\end{array}$ & & $\begin{array}{l}0.057^{* * * *} \\
(0.01)\end{array}$ & $\begin{array}{l}0.079^{* * *} \\
(0.01)\end{array}$ & $\begin{array}{l}0.061^{* * *} \\
(0.01)\end{array}$ & $\begin{array}{l}0.041^{* * *} \\
(0.01)\end{array}$ \\
\hline $\begin{array}{l}\text { Proportion of meat } \\
\text { exports }\end{array}$ & & & $\begin{array}{r}-1.337 \\
(1.07)\end{array}$ & $\begin{array}{c}0.523 \\
(1.09)\end{array}$ & $\begin{array}{r}-1.007 \\
(1.03)\end{array}$ \\
\hline $\begin{array}{l}\text { Proportion of fish } \\
\text { exports }\end{array}$ & & & $\begin{array}{r}0.575 \\
(0.61)\end{array}$ & $\begin{array}{c}0.764 \\
(0.57)\end{array}$ & $\begin{array}{c}0.319 \\
(0.58)\end{array}$ \\
\hline $\begin{array}{l}\text { Proportion of } \\
\text { vegetable and fruit } \\
\text { exports }\end{array}$ & & & $\begin{array}{l}1.848^{* * *} \\
(0.59)\end{array}$ & $\begin{array}{l}1.123^{* *} \\
(0.52)\end{array}$ & $\begin{array}{c}0.283 \\
(0.53)\end{array}$ \\
\hline $\begin{array}{l}\text { Proportion of urban } \\
\text { population }\end{array}$ & & & & & $\begin{array}{l}1.857^{* * *} \\
(0.58)\end{array}$ \\
\hline $\begin{array}{l}\text { Agricultural land size } \\
\quad\left(\text { million } \mathrm{km}^{2}\right)\end{array}$ & & & & & $\begin{array}{l}0.534^{* * *} \\
(0.16)\end{array}$ \\
\hline Common language & & & & & $\begin{array}{c}-0.113 \\
(0.27)\end{array}$ \\
\hline Colonial relationship & & & & & $\begin{array}{l}0.594^{*} \\
(0.33)\end{array}$ \\
\hline Contiguous border & & & & & $\begin{array}{l}2.438^{* * *} \\
(0.75)\end{array}$ \\
\hline Landlocked country & & & & & $\begin{array}{c}-0.600^{* *} \\
(0.26)\end{array}$ \\
\hline lnAlpha & $\begin{array}{l}1.602^{* * *} \\
(0.06)\end{array}$ & $\begin{array}{l}1.405^{* * *} \\
(0.06)\end{array}$ & $\begin{array}{l}1.505^{* * *} \\
(0.06)\end{array}$ & $\begin{array}{l}1.392^{* * *} \\
(0.06)\end{array}$ & $\begin{array}{l}1.304^{* * *} \\
(0.06)\end{array}$ \\
\hline Log likelihood & $-2,872.56$ & $-2,799.90$ & $-2,807.89$ & $-2,764.83$ & $-2,738.16$ \\
\hline Pseudo $R^{2}$ & 0.08 & 0.10 & 0.09 & 0.11 & 0.11 \\
\hline $\mathrm{N}$ & 786 & 786 & 780 & 780 & 780 \\
\hline
\end{tabular}

Notes: $* P<0.10, * * P<0.05, * * P<0.01$. Standard errors are in parentheses. Estimates of dummy variables for continents and standards are suppressed. EU, NA, and SA denote European Union, North America, and South America, respectively. 
require that all private brand suppliers become certified to one of the major food safety standards. In addition, the new FSMA signed into law in 2011 provides the FDA with the authority to require that high-risk imported foods be accompanied by a credible food safety certification. Though still not yet in effect at the time these data were collected, expectation of such policy also helps explain the significant impact of export proportion to North America. ${ }^{11}$

Column (3) differs from column (2) in that food export shares by product type replaced food export shares by destination. The coefficient of the proportion of vegetables and fruits exported is positive and statistically significant. Column (4) combined the specifications in the previous two columns. Results changed little from the previous two specifications. Finally, based on column (4), column (5) includes the additional set of control variables such as agricultural land size and colonial relationship. It is interesting to note that when the proportion of urban population was included, its effect was positive and statistically significant, whereas GDP and export shares of meat, fish, and vegetables and fruits became statistically insignificant. This likely tells us that the domestic middle class is more important in explaining the demand for certifications than is economic development. One caveat of this finding is that the urban population proportion and GDP have a correlation of 0.62 . In this full specification, the effects of certifiers and distance remain very robust.

As to trade, two variables remain robust: total food exports and the proportion of food exports to North America. We found that agricultural land size had a positive impact on certification adoption, which is consistent with our expectation. Sharing a border with a standard holder increased a country's demand for that standard. Being a landlocked country was linked to less demand for certification, confirming our hypothesis. Language or colonial relationships were not found to be statistically significant at the $5 \%$ level. One reason for the insignificant language effect is that many standards have versions for different languages.

The pseudo $R^{2}$ gradually increased from 0.08 for column (1) to 0.11 for column (5), which is reasonable for cross-sectional data. The improvement in the log likelihood from column (1) to column (4) is significant, whereas the improvement from column (4) to column (5) is much smaller, highlighting the importance of including the trade-related variables. Table 4 also reports the estimated value for the $\log$ of $\alpha$, the overdispersion parameter, which is larger than 1 in all specifications. The null hypothesis of equidispersion, that is, equal conditional mean and variance, is conclusively rejected because $\alpha$ is statistically significant. Such a result justifies the use of the negative binomial model over the Poisson model.

11 North America and Europe also have different phytosanitary restrictions. If exporters have had a long history supplying Europe (colonial relationships), then they may long ago have adapted to European standards. In this case, higher food exports to Europe are not likely to induce higher adoption of standards. 
Overall, a comparison of the five specifications shows that the main factors affecting a country's adoption of food safety certifications are the availability of domestic certification bodies, distance to standard holder's country, the degree of urbanization, land endowment, total food export value, and the weight of trade to North America. The first column of Table 5 reports the marginal effects based on the estimates in column (5) of Table 4, the full estimates. We found that an increase of one domestic certification body increased the number certified sites by 3.9 ; an increase of $1,000 \mathrm{~km}$ in distance to the standard holder reduced 1.5 certified sites; a 1 percentage point increase in the proportion of urban population increased 0.3 certified sites; a $\$ 1$ million increase in total food exports increased 0.6 certified sites; a 1 percentage point increase in the food export proportion to North America increased 0.8 certified sites; an increase of 1 million $\mathrm{km}^{2}$ in agricultural land increased 7.3 certified sites; sharing a border with the standard holder increased 33.3 certified sites; and being a landlocked country reduced 8.2 sites.

\subsection{Some Robustness Checks}

We further estimated several subsamples to examine the robustness of our results to different combinations of the standards. All results are based on the full specification in Table 4. Results are reported in Table 5. In the first robustness check (column 2), we combined the proportions of food exports to the European Union and North America. The logic is that when these two are separate, they may crowd out the effect of each other. The combined variable is not statistically significant. In the second check, we excluded GlobalGAP for two reasons. First, the scale of its adoption is about 10 times that for the other standards (Tables 1 and 2). So it is possible that the results are largely driven by the pattern of GlobalGAP adoption. Second, GlobalGAP is the only standard that exclusively focuses on farming. All the other six standards can be applied to food manufacturing and processing. Column (3) of Table 5 reports the results for this specification.

In the third robustness check, we broke the sample into farming standards (GlobalGAP, PrimusGFS, and SQF) versus exclusive manufacturing/processing standards (BRC, FSSC 22000, and ISO 22000) to investigate whether the adoption process is different between farming and manufacturing/processing standards. The last two columns of Table 5 report the findings. Several findings emerge from the last two robustness checks. First, the number of certification bodies, exports to North America, total food exports, and urban population remain very robust. Second, it seems distance matters for adopting farmingrelated standards but not for manufacturing standards. The distance parameter is significant at the $10 \%$ level in the farming standard specification. It becomes insignificant when GlobalGAP was excluded and turns positive and in the manufacturing standard specification. Third, interestingly we found that the 
Table 5. Marginal Effects plus Some Robustness Checks

\begin{tabular}{|c|c|c|c|c|c|}
\hline $\begin{array}{l}\text { Dependent Variable: } \\
\text { Number of Certified } \\
\text { Sites }\end{array}$ & $\begin{array}{l}\text { (1) Marginal } \\
\text { Effects }\end{array}$ & $\begin{array}{l}(2) \\
\text { Combined } \\
\text { EU and NA }\end{array}$ & $\begin{array}{l}\text { (3) Global- } \\
\text { GAP } \\
\text { Excluded }\end{array}$ & $\begin{array}{l}\text { (4) Farming } \\
\text { Standards }\end{array}$ & $\begin{array}{l}\text { (5) Manu- } \\
\text { facturing } \\
\text { Standards }\end{array}$ \\
\hline $\begin{array}{l}\text { Number of } \\
\text { certification bodies }\end{array}$ & $3.893^{* * *}$ & $\begin{array}{l}0.282^{* * *} \\
(0.05)\end{array}$ & $\begin{array}{l}0.265^{* * *} \\
(0.05)\end{array}$ & $\begin{array}{l}0.550^{* *} \\
(0.23)\end{array}$ & $\begin{array}{l}0.252^{* * *} \\
(0.03)\end{array}$ \\
\hline $\begin{array}{l}\text { Distance to standard } \\
\text { holder's country } \\
(1,000 \mathrm{~km})\end{array}$ & $-1.526^{* * *}$ & $\begin{array}{c}-0.105^{* * *} \\
(0.04)\end{array}$ & $\begin{array}{c}-0.024 \\
(0.04)\end{array}$ & $\begin{array}{c}-0.152^{*} \\
(0.09)\end{array}$ & $\begin{array}{l}0.077^{* *} \\
(0.04)\end{array}$ \\
\hline $\begin{array}{l}\text { Per capita GDP } \\
\qquad(\$ 1,000)\end{array}$ & 0.033 & $\begin{array}{c}0.008 \\
(0.01)\end{array}$ & $\begin{array}{c}0.005 \\
(0.01)\end{array}$ & $\begin{array}{c}-0.014 \\
(0.02)\end{array}$ & $\begin{array}{c}0.00 \\
(0.01)\end{array}$ \\
\hline $\begin{array}{l}\text { Proportion of food } \\
\text { exports to EU and } \\
\text { NA }\end{array}$ & & $\begin{array}{c}0.795 \\
(0.76)\end{array}$ & & & \\
\hline $\begin{array}{l}\text { Proportion of food } \\
\text { exports to EU }\end{array}$ & 2.782 & & $\begin{array}{r}0.415 \\
(0.80)\end{array}$ & $\begin{array}{c}0.13 \\
(2.24)\end{array}$ & $\begin{array}{r}0.849 \\
(0.66)\end{array}$ \\
\hline $\begin{array}{l}\text { Proportion of food } \\
\text { exports to NA }\end{array}$ & $74.221^{* * *}$ & & $\begin{array}{l}3.770^{* * *} \\
(1.32)\end{array}$ & $\begin{array}{l}8.745^{* *} \\
(3.58)\end{array}$ & $\begin{array}{l}2.438^{* *} \\
(1.08)\end{array}$ \\
\hline $\begin{array}{l}\text { Proportion of food } \\
\text { exports to SA }\end{array}$ & 37.137 & $\begin{array}{c}-0.413 \\
(1.48)\end{array}$ & $\begin{array}{l}2.808 \\
(1.89)\end{array}$ & $\begin{array}{r}-3.614 \\
(5.30)\end{array}$ & $\begin{array}{l}4.598^{* * *} \\
(1.70)\end{array}$ \\
\hline $\begin{array}{l}\text { Proportion of food } \\
\text { exports to Asia }\end{array}$ & 13.481 & $\begin{array}{c}0.623 \\
(0.96)\end{array}$ & $\begin{array}{l}1.044 \\
(0.94)\end{array}$ & $\begin{array}{c}2.41 \\
(2.51)\end{array}$ & $\begin{array}{c}0.086 \\
(0.74)\end{array}$ \\
\hline $\begin{array}{l}\text { Proportion of food } \\
\text { exports to Africa }\end{array}$ & -0.839 & $\begin{array}{r}0.017 \\
(0.94)\end{array}$ & $\begin{array}{c}-0.106 \\
(0.93)\end{array}$ & $\begin{array}{r}-0.422 \\
(2.34)\end{array}$ & $\begin{array}{c}0.078 \\
(0.82)\end{array}$ \\
\hline $\begin{array}{l}\text { Total food exports } \\
\text { (\$1 million) }\end{array}$ & $0.556^{* * *}$ & $\begin{array}{l}0.041^{\text {**** }} \\
(0.01)\end{array}$ & $\begin{array}{l}0.039^{* * *} \\
(0.01)\end{array}$ & $\begin{array}{l}0.044^{* *} \\
(0.02)\end{array}$ & $\begin{array}{l}0.047^{* * *} \\
(0.01)\end{array}$ \\
\hline $\begin{array}{l}\text { Proportion of meat } \\
\text { exports }\end{array}$ & -13.771 & $\begin{array}{c}-1.474 \\
(1.01)\end{array}$ & $\begin{array}{c}-1.053 \\
(1.06)\end{array}$ & $\begin{array}{r}-0.635 \\
(3.21)\end{array}$ & $\begin{array}{r}-0.939 \\
(0.88)\end{array}$ \\
\hline $\begin{array}{l}\text { Proportion of fish } \\
\text { exports }\end{array}$ & 4.358 & $\begin{array}{c}0.171 \\
(0.60)\end{array}$ & $\begin{array}{r}-0.01 \\
(0.58)\end{array}$ & $\begin{array}{l}3.167^{* *} \\
(1.54)\end{array}$ & $\begin{array}{c}-1.055^{* *} \\
(0.42)\end{array}$ \\
\hline $\begin{array}{l}\text { Proportion of } \\
\text { vegetable and fruit } \\
\text { exports }\end{array}$ & 3.872 & $\begin{array}{c}0.463 \\
(0.53)\end{array}$ & $\begin{array}{c}0.254 \\
(0.53)\end{array}$ & $\begin{array}{c}0.618 \\
(1.26)\end{array}$ & $\begin{array}{r}0.675 \\
(0.45)\end{array}$ \\
\hline $\begin{array}{l}\text { Proportion of urban } \\
\text { population }\end{array}$ & $25.389^{* * *}$ & $\begin{array}{l}1.625^{\text {**** }} \\
(0.59)\end{array}$ & $\begin{array}{l}1.928^{* * *} \\
(0.58)\end{array}$ & $\begin{array}{l}3.883^{* * *} \\
(1.47)\end{array}$ & $\begin{array}{l}0.835^{*} \\
(0.51)\end{array}$ \\
\hline $\begin{array}{l}\text { Agricultural land size } \\
\quad\left(\text { million } \mathrm{km}^{2}\right)\end{array}$ & $7.298^{* * *}$ & $\begin{array}{l}0.497^{* * * *} \\
(0.16)\end{array}$ & $\begin{array}{l}0.454^{* * *} \\
(0.16)\end{array}$ & $\begin{array}{c}0.482 \\
(0.35)\end{array}$ & $\begin{array}{l}0.332^{* *} \\
(0.14)\end{array}$ \\
\hline Common language & -1.549 & $\begin{array}{r}-0.247 \\
(0.27)\end{array}$ & $\begin{array}{r}-0.14 \\
(0.29)\end{array}$ & $\begin{array}{c}0.341 \\
(0.58)\end{array}$ & $\begin{array}{r}-0.079 \\
(0.27)\end{array}$ \\
\hline Colonial relationship & $8.115^{*}$ & $\begin{array}{c}0.638^{*} \\
(0.33)\end{array}$ & $\begin{array}{l}0.579^{*} \\
(0.33)\end{array}$ & $\begin{array}{r}-0.767 \\
(0.97)\end{array}$ & $\begin{array}{l}0.733^{* *} \\
(0.31)\end{array}$ \\
\hline Contiguous border & $33.335^{* * *}$ & $\begin{array}{l}4.224^{* * *} \\
(0.62)\end{array}$ & $\begin{array}{c}0.953 \\
(0.65)\end{array}$ & $\begin{array}{c}0.949 \\
(1.66)\end{array}$ & $\begin{array}{r}-0.027 \\
(0.61)\end{array}$ \\
\hline Landlocked country & $-8.199^{* *}$ & $\begin{array}{c}-0.742^{* * *} \\
(0.26)\end{array}$ & $\begin{array}{c}-0.726^{* * *} \\
(0.26)\end{array}$ & $\begin{array}{c}0.074 \\
(0.62)\end{array}$ & $\begin{array}{c}-0.981^{* * *} \\
(0.23)\end{array}$ \\
\hline lnAlpha & & $\begin{array}{l}1.325^{* * *} \\
(0.06)\end{array}$ & $\begin{array}{l}1.218^{* * *} \\
(0.06)\end{array}$ & $\begin{array}{l}1.981^{* * * *} \\
(0.10)\end{array}$ & $\begin{array}{l}0.475^{\text {*** }} \\
(0.07)\end{array}$ \\
\hline
\end{tabular}


Table 5. Continued

\begin{tabular}{llllll}
\hline \hline Dependent Variable: & & (2) & (3) Global- & & (5) Manu- \\
Number of Certified & (1) Marginal & Combined & GAP & (4) Farming & $\begin{array}{l}\text { facturing } \\
\text { Sites }\end{array}$ \\
\cline { 3 - 5 } & Effects & EU and NA & Excluded & Standards & Standards \\
\hline Log likelihood & & $-2,745.75$ & $-2,650.05$ & -910.05 & $-1,691.60$ \\
Pseudo $R^{2}$ & & 0.11 & 0.09 & 0.13 & 0.11 \\
$\mathrm{~N}$ & & 780 & 650 & 390 & 390 \\
\hline \hline
\end{tabular}

Notes: $* P<0.10, * * P<0.05, * * P<0.01$. Standard errors are in parentheses. Estimates of dummy variables for continents and standards are suppressed. EU, NA, and SA denote European Union, North America, and South America, respectively. Farming standards are GlobalGAP (Global Good Agricultural Practices), PrimusGFS (developed by PrimusLab as a Global Food Safety Initiative variant), and SQF (Safe Quality Food). Exclusive manufacturing standards are BRC (British Retail Consortium Food Standard), FSSC 22000 (Food Safety System Certification 22000), and ISO 22000 (International Organization for Standardization 22000).

proportion of fish exports is positive in the farming standard specification and negative in the manufacturing standard specification.

\section{Conclusion}

We examined the cross-national adoption of private food safety standards, focusing on the role of certifiers and international trade. Applying a negative binomial model to pooled cross-sectional data for 131 countries over six major standards, we obtained several results that might have important policy and marketing implications. First, we found that distance to the standard holder will negatively affect the number of certified sites in a country to that standard. Such effect particularly holds for adopting farming-related standards. In other words, distance created product differentiation for standards. Meanwhile, per capita GDP has a positive impact on a country's certification adoption. The entire major private food safety standards are either based in the United States or Europe. Developing countries in Africa and Asia clearly are at a disadvantage in adopting food safety standards because they are farther away from the standard holders (likely faced with a higher certification cost).

From the perspectives of development and food safety, what can we do to accelerate the adoption of food safety certification in developing countries (given that there is not much we can change about GDP or urbanization)? One policy recommendation, based on our finding of the negative relationship between distance and certification adoption, is to create a competing food safety standard that is based in a developing country in Africa and/or Asia. However, given that there are already a handful of well-established standards in the market, establishing a new competing standard seems difficult. A better and more costeffective alternative is to provide developing countries with better access to the existing standards. We found that the number of domestic certification bodies 
had a positive and very robust effect on a country's adoption of food safety standards. In fact, the marginal effects show that an increase of one domestic certification body increased the number certified sites by 3.9, which is equivalent to the effect of a 15 percentage point increase in the proportion of population in urban areas. One such recommendation is to provide certification training programs for distant developing countries (from the standard holders) and/or training students coming from those countries in developed countries.

Second, we found total food exports had a positive impact on a country's certification adoption, likely because of importers' requirements and/or exporters' strategy of using certification to gain market access. We also found that in additional to the total size of food exports, the composition of exporting partners matters. In particular, a higher proportion of food exports to North America increased the demand for certification, suggesting that probably North America has the strongest demand or requirements for food safety certification. Because the data we used were before the full implementation of the FSMA, likely the buyers' demand from the private sector (e.g., U.S. retailers) largely drove our results. The full implementation of the FSMA likely will strengthen this effect. Future studies may want to further analyze the impact of the export shares of processed and unprocessed food as well. We want to emphasize two areas that are worth exploring further. One is the producer's choice of which standard to certify to. The other is how much the certification cost, which is paid by producers, is passed through to consumers in the form of a price increase. Finally, one caveat of our study is the use of cross-sectional data. Future studies in this area are encouraged to employ panel data. First, panel data will make good use of the explosive increase in certified sites in recent years (a great source of variation). Second, panel data will allow researchers to better test for the causal connection between certification and trade, as well as to build a full structural model that examines not only the impact of trade on certification adoption (e.g., using lagged variable), but also how certification improves trade. Our study only focuses on the former issue, by assuming exogeneity of trade.

\section{References}

Asfaw, S., D. Mithöfer, and H. Waibel. "Agrifood Supply Chain, Private-Sector Standards, and Farmers' Health: Evidence from Kenya." Agricultural Economics 41(February 2010):251-63.

—. "Investment in Compliance with GlobalGAP Standards: Does It Pay Off for SmallScale Producers in Kenya?” Quarterly Journal of International Agriculture 48(January 2009):337-62.

Barrett, H.R., A.W. Browne, P.J.C. Harris, and K. Cadoret. "Organic Certification and the UK Market: Organic Imports from Developing Countries.” Food Policy 27(July 2002):30118.

Global Food Safety Initiative. "Recognised Schemes.” Internet site: http://www.mygfsi.com/ schemes-certification/recognised-schemes.html (Accessed April 1, 2015). 
Greene, W.H. Econometric Analysis. 7th ed. Upper Saddle River, NJ: Prentice Hall, 2012.

Hatanaka, M., C. Bain, and L. Busch. "Third-Party Certification in the Global Agrifood System." Food Policy 30(June 2005):354-69.

Henson, S., O. Masakure, and J. Cranfield. "Do Fresh Produce Exporters in Sub-Saharan Africa Benefit from GlobalGAP Certification?” World Development 39(March 2011):375-86.

Herzfeld, T., L.S. Drescher, and C. Grebitus. "Cross-National Adoption of Private Food Quality Standards.” Food Policy 36(June 2011):401-11.

Holzapfel, S., and M. Wollni. "Is GlobalGAP Certification of Small-Scale Farmers Sustainable? Evidence from Thailand.” Journal of Development Studies 50(February 2014):731-47.

International Organization for Standardization (ISO). "ISO Survey of Certifications." Internet site: http://www.iso.org/iso/iso-survey (Accessed December 31, 2013).

Jongwanich, J. "The Impact of Food Safety Standards on Processed Food Exports from Developing Countries.” Food Policy 34(October 2009):447-57.

Kanter, C., K.D. Messer, and H.M. Kaiser. "Does Production Labeling Stigmatize Conventional Milk?" American Journal of Agricultural Economics 91(November 2009):1097-109.

Kariuki, I.M., J.P. Loy, and T. Herzfeld. "Farmgate Private Standards and Price Premium: Evidence from the GlobalGAP Scheme in Kenya's French Beans Marketing." Agribusiness: An International Journal 28(April 2012):42-53.

Liaukonyte, J., N.A. Streletskaya, H.M. Kaiser, and B. Rickard. "Consumer Response to 'Contains' and 'Free of' Labeling: Evidence from Lab Experiments.” Applied Economic Perspectives and Policy 35(June 2013):476-507.

Lim, K.H., W. Hu, L.J. Maynard, and E. Goddard. “A Taste for Safer Beef? How Much Does Consumers' Perceived Risk Influence Willingness to Pay for Country-of-Origin Labeled Beef." Agribusiness: An International Journal 30(January 2014):17-30.

Loureiro, M.L., and W.J. Umberger. "A Choice Experiment Model for Beef: What US Consumer Responses Tell Us about Relative Preferences for Food Safety, Country-ofOrigin Labeling and Traceability." Food Policy 32(August 2007):496-514.

Mayer, T., and S. Zignago. "Notes on CEPII's Distances Measures: The GeoDist Database." Centre d'Etudes Prospectives et d'Informations Internationales (CEPII) Working Paper No. 2011-25, Paris: CEPII, 2011.

McCluskey, J.J., and M.L. Loureiro. "Consumer Preferences and Willingness to Pay for Food Labeling: A Discussion of Empirical Studies.” Journal of Food Distribution Research 34(November 2003):95-102.

Meas, T., W. Hu, M. Batte, T. Woods, and S. Ernst. "Substitutes or Complements? Consumer Preferences for Local and Organic Food Attributes.” American Journal of Agricultural Economics 97(July 2015):1044-71.

Neumayer, E., and R. Perkins. "Uneven Geographies of Organizational Practice: Explaining the Cross-National Transfer and Diffusion of ISO 9000." Economic Geography 81(July 2005):237-59.

Otsuki, T., J. Wilson, and M. Sewadeh. "Saving Two in a Billion: Quantifying the Trade Effect of European Food Safety Standards on African Exports." Food Policy 26(October 2001a):495-514.

—. "What Price Precaution? European Harmonisation of Aflatoxin Regulations and African Groundnut Exports." European Review of Agricultural Economics 28(October 2001b):263-84.

Peterson, E., J. Grant, D. Roberts, and V. Karov. "Evaluating the Trade Restrictiveness of Phytosanitary Measures on U.S. Fresh Fruit and Vegetable Imports. American Journal of Agricultural Economics 95(July 2013):842-58. 
Reardon, T., C.P. Timmer, C.B. Barrett, and J. Berdegué. "The Rise of Supermarkets in Africa, Asia, and Latin America." American Journal of Agricultural Economics 85(December 2003):1140-46.

Runge, C.F., and L.A. Jackson. "Negative Labeling of Genetically Modified Organisms (GMOs): The Experience of rBST." AgBioForum 3,1(2000):58-62.

Subervie, J., and I. Vagneron. "A Drop of Water in the Indian Ocean? The Impact of GlobalGap Certification on Lychee Farmers in Madagascar." World Development 50(October 2013):57-73.

United Nations Commodity Trade Statistics Database (UN Comtrade). Internet site: http:// comtrade.un.org/db/ (Accessed January 2, 2015).

U.S. Department of Agriculture, Food Safety and Inspection Service. "Recall Case Archive.” Internet site: http:/www.fsis.usda.gov/wps/portal/fsis/topics/ recalls-and-public-health-alerts/recall-case-archive (Accessed May 1, 2015).

U.S. Food and Drug Administration. "Accreditation of Third-Party Certification Bodies to Conduct Food Safety Audits and to Issue Certifications, Final Regulatory Impact Analysis." Federal Register 80,228(2011):74569-74667.

. “Archive for Recalls, Market Withdrawals \& Safety Alerts.” Internet site: http://www. fda.gov/safety/recalls/archiverecalls/default.htm (Accessed May 1, 2015).

The World Bank. "World Development Indicators.” Internet site: http://data.worldbank.org/ data-catalog/world-development-indicators (Accessed December 31, 2013).

Zheng, Y., M.K. Muth, and J. Brophy. "The Impact of Food Safety Third-Party Certifications on China's Food Exports to the United States." Paper presented at the Agricultural and Applied Economics Association Annual Meeting, Washington, DC, August 4-6, 2013. 